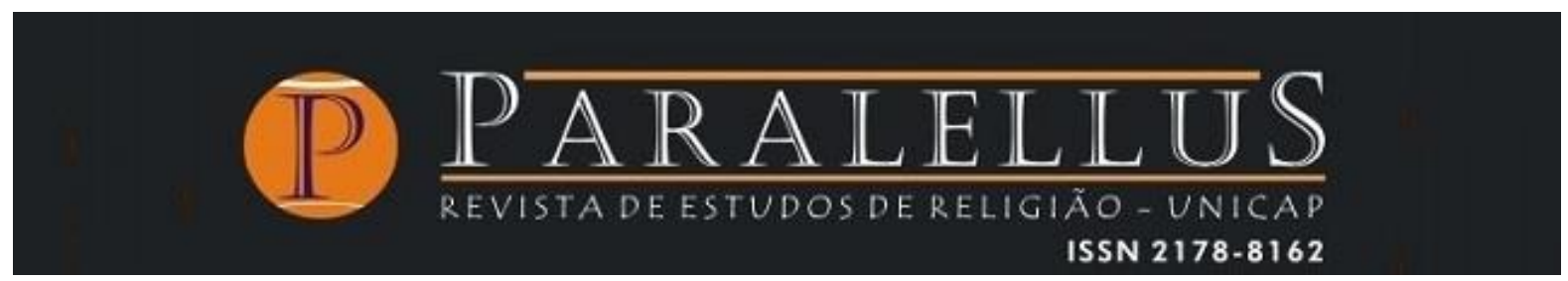

Volume 12 - Número 30

DOSSIÊ: INTERPRETAÇÃO PLURALISTA DAS RELIGIÕES

doi: 10.25247/paralellus.2021.v12n30.p469-486

\title{
PROVÉRBIOS E DITOS NA BOCA DO SÁBIO POPULAR JESUS DE NAZARÉ
}

\author{
PROVERBS AND SAYINGS IN THE MOUTH OF THE POPULAR SAGE \\ JESUS OF NAZARETH
}

Valmor da Silva*

\section{RESUMO}

Analisa diversos aspectos da familiaridade de Jesus com o uso de ditados e provérbios, conforme relatado pelos Evangelhos, na esteira da tradição sapiencial. Explica a fonte desses ditos, identificada como fonte $Q$, o evangelho radical da Galileia. Distingue a identificação de Jesus como "a Sabedoria" (sofia ou logos), "filho da Sabedoria" da outra identificação de Jesus como sábio popular, contador de parábolas, ditos e provérbios. Desenvolve mais o segundo aspecto, com algumas características de Jesus, reconhecido como sábio popular, pelas citações de provérbios do Antigo testamento, pelo uso de provérbios da literatura rabínica e da greco-romana, pela composição de parábolas a partir de provérbios, pelo seu apelo para o paradoxo, a hipérbole e o humor. Argumenta pelo uso de provérbios por Jesus, no contexto existencial, com a finalidade didática de provocar e sacudir seus ouvintes, em vista de uma mudança existencial e social. Metodologicamente, agrupa, classifica e compara as expressões proverbiais, com o objetivo de destacar essa atividade sapiencial intensa de Jesus. Conclui, como resultado, uma característica importante, e nem sempre bem explorada, na vida de Jesus, segundo os Evangelhos.

Palavras-chave: Provérbios; Jesus histórico; fonte Q; sabedoria.

\footnotetext{
" Doutor em Ciências da Religião pela Universidade Metodista de São Paulo. Pós-Doutor em Teologia pela Faculdade Jesuíta de Belo Horizonte. Professor no Programa de Pós-Graduação em Ciências da Religião da PUC Goiás.
} 


\section{ABstract}

It analyzes several aspects of Jesus' familiarity with the use of sayings and proverbs, as reported by the Gospels, in the wake of the wisdom tradition. Explains the source of these sayings, identified as source $Q$, the radical gospel of Galilee. It distinguishes the identification of Jesus as "the Wisdom" (sofia or logos), "son of Wisdom" from the other identification of Jesus as a popular sage, teller of parables, sayings and proverbs. It further develops the second aspect, with some characteristics of Jesus, recognized as a popular sage, by citing Old Testament proverbs, by using proverbs from rabbinic and Greek-Roman literature, by composing parables from proverbs, by his appeal for paradox, hyperbole and humor. It argues for the use of proverbs by Jesus, in the existential context, with the didactic purpose of provoking and shaking his listeners, in view of an existential and social change. Metodologicamente, agrupa, classifica e compara as expressões proverbiais, com o objetivo de destacar essa atividade sapiencial intensa de Jesus. It concludes, as a result, an important feature, and not always well explored, in the life of Jesus, according to the Gospels.

Keywords: Proverbs; Historical Jesus; Q source; Wisdom.

\section{INTRODUÇÃO}

Na leitura dos quatro Evangelhos canônicos, constata-se a presença de inúmeros provérbios, ditados e aforismos atribuídos a Jesus. Alguns dados estatísticos demonstram isso, segundo os principais autores que estudam o assunto. Só nos Evangelhos Sinóticos, contam-se 133 aforismos, segundo Crossan; 102 conforme Carlston; ou 108 na avaliação de Küchler, como nos informa Piper (1989, p. 2). Essa diversidade numérica se deve, entre outros fatores, à definição de provérbio adotada e aos critérios para identificá-los em seu contexto literário.

Seja como for, a quantidade de ditos encontrada nos Evangelhos, além de parábolas e comparações, demonstra a familiaridade de Jesus com esse gênero popular do seu tempo. Especialmente familiar a Jesus era o livro de Provérbios, do Antigo Testamento. A esse respeito, escreveu há muitos anos Horton (1888, p. 108): "Nenhum livro da Bíblia Ele estudou mais, nenhum livro da Bíblia Ele enriqueceu, ampliou e melhorou tanto". ${ }^{1}$

1 Horton (1888, p. 105-123), muito antes da proposta da teoria das fontes, escreve um interessante artigo com muitos exemplos sobre o uso do livro de Provérbios por Jesus, especialmente no 
A terminologia moderna, para o conceito de "provérbio" é diversificada e inclui diferentes classificações. Na linguagem fluente, em português, usa-se em geral ditado ou provérbio. Mas a crítica literária recente tem se esmerado em detalhar as definições dos diversos termos que descrevem essa linguagem de Jesus. Hedrick (2014, p. 81) traz uma lista com a definição de doze termos, sendo: dito/sofisma, hipérbole, ambiguidade, humor, sabedoria, sumário, idioma, aforismo, provérbio, paradoxo, juízo e sofisma. ${ }^{2}$

O grego do Novo Testamento, alheio a essa diversidade terminológica, usa habitualmente os termos parábola (parabolé) e comparação (paroimia), sendo parábola mais predominante nos Sinóticos, e comparação no Evangelho de João. Parabolé ocorre cinquenta vezes no Novo Testamento, das quais quarenta e oito nos Sinóticos, e duas em Hebreus (DIAS DA SILVA, 2019, p. 18-19).

Os termos parábola e provérbio, que expressam gêneros diferentes, não possuem duas palavras correspondentes em grego nem em hebraico. As línguas da Bíblia Hebraica, do Antigo Testamento, possuem uma só palavra (mašal em hebraico, igual a mathla em aramaico) para se referir tanto a parábola quanto a provérbio. ${ }^{3} \mathrm{O}$ substantivo mašal, da raiz mšl, ligada à ideia de "ser semelhante a" ou "parecer com", designa vários tipos de discurso, como dito popular ou provérbio, dito sapiencial, discurso didático, escárnio, vaticínio ou oráculo profético, ensinamento dos sábios, linguagem figurada em geral. Por vezes, possui um termo associado, hidah, que corresponde a "enigma" (DIAS DA SILVA, 2019, p. 16-17).

Seja através do uso de parábolas, seja através de ditados, Jesus demonstra familiaridade com a sabedoria popular, com domínio da linguagem do seu entorno, tanto da Palestina quanto do mundo greco-romano. Embora os provérbios sejam mais frequentes que as parábolas, nos Evangelhos, eles têm merecido menos

Sermão da Montanha (Mt 5-7), considerando Jesus como a Sabedoria encarnada, em vista do universalismo da Sabedoria e do ensino de Jesus.

${ }^{2}$ A tradução desses termos, do inglês para o português, nem sempre é fácil e clara. Crossan (1983, p. 3) elenca: adágio, aforismo, apotegma, epigrama, fragmento, gnome, provérbio, máxima, sentença e dito. Piper (1989, p. 1-3) apresenta a terminologia da retórica grega: creia (do grego chreia ou chria) é o dito de um personagem importante; apotegma é o dito que contém norma de conduta; aforismo é a sentença lapidar, curta, condensada e surpreendente, semelhante ao provérbio.

3 Segundo Hamilton (1998, p. 889-890), provérbio caracteriza dito breve, como máxima moral; enquanto parábola é o provérbio ampliado. 
atenção por parte dos estudiosos. Em vista disso, o presente estudo procura analisar a familiaridade de Jesus com a sabedoria popular, expressa em provérbios, ditos e expressões proverbiais. Com expressões e imagens do dia a dia, no seu contexto existencial, Jesus usava tantos provérbios, com a finalidade de provocar e sacudir seus ouvintes. ${ }^{4}$

\section{FONTE DOS DITOS DE JESUS}

Ditos e provérbios constituem literatura popular. Nascem espontaneamente, a partir da experiência do dia a dia, nas mais diversas situações da vida. Em sua origem, são anônimos, e assim são difundidos, de boca em boca (SILVA, 2018, p. 124-125). ${ }^{5}$

No caso de Jesus, como foram transmitidos tantos provérbios transcritos nos Evangelhos? A transmissão desses ditos passou por um período oral de pelo menos duas gerações. Conservados na memória de discípulos, os ditos de Jesus foram repetidos, interpretados e adaptados a contextos diferentes (HEDRICK, 2014, p. 7778). Segundo cálculos do Jesus Seminar ${ }^{6}, 18 \%$ dos ditos atribuídos a Jesus, nos Evangelhos, são provavelmente originais da boca de Jesus, isto é, pronunciados pelo Jesus de Nazaré, em sua atuação histórica na Galileia (HEDRICK, 2014, p. 80).

Como se deu o processo de transmissão e recriação dos ditos, a partir de Jesus, até a redação final dos Evangelhos? Embora não haja uma resposta definitiva a essa pergunta, a teoria explicativa mais aceita entre quem pesquisa é a chamada teoria da fonte Q. Uma síntese sobre essa teoria é apresentada a seguir, de acordo com Vaage (1995, p. 84-108). ${ }^{7}$

\footnotetext{
${ }^{4}$ Ferreira (2020) faz um amplo estudo sobre o aspecto pedagógico dos provérbios de Jesus.

${ }^{5}$ No livro citado, apresento a discussão sobre a classe social dos autores do livro de Provérbios, para argumentar que, "antes de terem sido escritos, os ditados bíblicos circulavam, por séculos e séculos, como sabedoria popular, oral, portanto como produção literária da classe baixa, popular, trabalhadora" (SILVA, 2018, p. 123). Como expressa a pesquisadora Gabriela Funk: "é o povo o verdadeiro transmissor do provérbio" (FUNK, 1998, p. 97).

6 Jesus Seminar é um grande projeto de pesquisa sobre o Jesus histórico, fundado nos Estados Unidos em 1985 e que busca, através da crítica histórica, esclarecer o que é palavra autêntica de Jesus e o que é tradição das comunidades e dos evangelistas. No Brasil há diversos grupos de pesquisa em torno ao Jesus histórico (CHEVITARESE; FUNARI, 2012, p. 54-63).

7 A aceitação da teoria da fonte $Q$ é praticamente uma unanimidade nos estudos sobre a origem dos Evangelhos. Para uma exposição geral sobre a teoria, incluindo uma tradução dos ditos, pode-se consultar: Guijarro Oporto (2006).
} 
A partir da crítica das formas (the form-critics ou, como no original alemão, Formgeschichte, história das formas), levanta-se a hipótese da existência de uma fonte de ditos (logia) de Jesus, chamada fonte $Q$, da palavra alemã Quelle, que significa justamente fonte. Essa fonte de ditos (logia) manifesta a habilidade de Jesus no emprego da forma aforística ou proverbial.

A fonte $Q$ de ditos (logia) é a reconstrução hipotética de um documento original anterior à redação dos sinóticos, e que serviu como base para os evangelhos de Mateus e Lucas, ao lado da outra fonte, que foi o evangelho de Marcos.

A fonte $Q$ seria proveniente da Galileia, mais especificamente, dos arredores do Lago de Genesaré, e teria sido sistematizada por volta da década de 40, portanto logo após a morte de Jesus. Essa fonte teria passado por três etapas redacionais. A primeira foi uma coleção "sapiencial" dos ditos de Jesus com o gênero literário da "instrução". A segunda foi tipo "gomologion" (uma relação de vários pronunciamentos), que introduziu o discurso "profético", polêmico e desafiador. A terceira, com tendência biográfica de Jesus, introduziu o relato das três "tentações" e um par de ditos.

Na fonte $Q$ predominam, portanto, os ditos de Jesus, isto é, sentenças breves e diretas, sem referência a paixão, morte e ressurreição, mínima referência a milagres e poucos relatos de parábolas.

A fonte $Q$ tem semelhanças com o Evangelho de Tomé. Ambos possuem a mesma base sapiencial, do gênero literário "ditos dos sábios" (logoi sophon), tendo como ponto de partida o livro bíblico de Provérbios. Enquanto Tomé toma a tendência gnóstica, Q passa para o gênero apocalíptico. ${ }^{8}$

A fonte $Q$ representaria, pois, um "Evangelho radical", com proposta de rompimento com a estrutura social; releitura das tradições judaicas e desprendimento material (RODRIGUES, 2008, p. 51). Jesus seria visto, segundo essa interpretação, como um profeta escatológico-apocalíptico, sábio popular, por meio de sua pregação

\footnotetext{
${ }^{8}$ Rodrigues (2008, p. 51-64) faz uma avaliação crítica dessa "matriz apocalíptica", em favor de uma tendência desenvolvida no Brasil, segundo a qual, "as tradições sapienciais de $Q$ teriam sido profundamente marcadas pela tradição judaica, pela sabedoria e pela memória de Israel" (p. 61). Sobre a sabedoria no Evangelho de Tomé, pode-se consultar Patterson (1993, p. 187-221).
} 
ambulante, a pronunciar provérbios, ditos e sentenças a fim de provocar o povo de sua época, no contexto específico da Galileia sob o domínio do Império Romano (SCHIAVO; SILVA, 2002, p. 101-5).

Essas duas maneiras de considerar e de descrever a pessoa e a atividade de Jesus, como profeta e como sábio, não se acham em contradição. $\mathrm{Na}$ verdade, elas se complementam, oferecendo um melhor quadro da vida e do ministério de Jesus (CERESKO, 2004, p. 187).

Se, por um lado, os dados do Evangelho e as pesquisas críticas confirmam a tradição sapiencial de Jesus, por outro, a interpretação desse dado não é unânime. Nos Evangelhos, Jesus pode ser identificado como "a Sabedoria" (sofia ou logos), o "filho da Sabedoria", como também pode ser identificado como sábio popular, contador de parábolas, ditos e provérbios (NICCACCI, 1997, p. 285-288). pesquisador vietnamita Dinh Anh Nhue Nguyen estampa esse duplo aspecto, no título de seu livro "Jesus o sábio de Deus e a Sabedoria divina". Ao expor o estado da pesquisa sobre o assunto, ele conclui que:

Apesar da presença do forte e vivo interesse pelo tema de Jesus o sábio e pela questão teológica de Jesus Sabedoria divina, são poucos ou falta verdadeiramente um estudo, ao menos em língua italiana, que junte as duas dimensões temáticas que, em nossa opinião, aparecem inseparável nas tradições sinóticas (NGUYEN, 2017, p. 15).

Já no presente estudo, privilegiamos o aspecto de Jesus sábio, ou mestre de sabedoria, pelo seu uso de ditos, provérbios e aforismos. Trata-se de uma valorização do Jesus histórico, ou de uma visão de Jesus Cristo a partir de sua humanidade, chamada cristologia ascendente, com uma visão de baixo para cima. Para melhor esclarecimento, entretanto, o próximo item aborda, sinteticamente, o outro aspecto, Cristo Jesus como a Sabedoria divina, conhecida como cristologia descendente, a partir da divindade de Jesus, visão de cima para baixo.

\section{JESUS É A SABEDORIA PERSONIFICADA}

A interpretação do cristianismo primitivo teria entendido o significado universal de Jesus Cristo em termos da tradição sapiencial. Jesus seria o Logos, isto é, a sabedoria de Deus. Assim sendo, essa realidade estaria presente já na chamada 
fonte $Q$, na qual Cristo seria visto como Sabedoria ou, ao menos, em termos sapienciais (BEARDSLEE, 1970, p. 62).

No Evangelho de Marcos, especificamente na chamada seção dos pães (Mc 6,308,21 ) Jesus é apresentado como a figura da sabedoria da tradição literária de Israel, especialmente de Provérbios e Sirácida, que distribui o pão do ensinamento às multidões que o seguem. A mesma tese pode ser verificada em diversos outros textos do Novo Testamento (HUMPHREY, 1989, p. 48-53).

Na tradição bíblica, a sabedoria pode ser personificada. Quer dizer que ela assume uma identidade autônoma e até distinta de Deus. A personificação "consiste em fazer passar como pessoa algo que não o é, como uma abstração, uma planta, um animal" (VÍLCHEZ LÍNDEZ, 1999, p. 83). A sabedoria passa a ser uma mulher que aconselha, convida e acompanha as pessoas. Também é personificada a virtude contrária, como a senhora insensatez. O hábito de personificar virtudes não é novidade, como a justiça, representada por uma mulher com balança, a medicina como uma serpente, a morte como um esqueleto com alfanje ou o mal como um bode. A tradição franciscana personificou a pobreza, como a noiva com quem Francisco se casou. Já no mundo mais antigo, os egípcios personificaram a sabedoria como Maat, a deusa menina. Os gregos representavam a sabedoria como coruja, ave noturna, vigilante e perspicaz, símbolo, até hoje, da filosofia.

Também outras realidades abstratas são personificadas. "Justiça e paz se abraçarão" (SI 85,11). Pode-se ler, a propósito, também o SI 85,11-14 (SI 79,8). A própria Palavra de Deus é personificada, como a chuva, não volta sem ter cumprido sua missão (Is 55,11), como martelo, espada, bomba (Is 9,7.17.20), ou então a peste e a febre (Hab 3,5).

Alguns exemplos, nos Evangelhos, demonstram a expressão de Jesus como a sabedoria (sofia) personificada. Na transfiguração, no monte Tabor, teríamos a representação das três coletâneas que compõem a Bíblia Hebraica, estando Jesus no meio como a sabedoria. Aparecem, efetivamente, Moisés (torá) e Elias (nebiîm) ao lado de Jesus (ketubîm) (Lc 9,30). No diálogo com Marta, Jesus representa a sabedoria que sai ao encontro, na rua (Jo 11). Igualmente no verbo (logos) feito 
carne (Jo 1,1-14). E ainda, Jesus é a sabedoria do Pai, em afirmações como "Eu sou o caminho, a verdade e a vida" (Jo 14,6).

Alguns exemplos a mais relacionam Cristo com a sabedoria: "Mas aqui está algo mais do que Salomão" (Mt 12,42); "De onde lhe vêm essa sabedoria e esses milagres?" (Mt 13,54); "E Jesus crescia em sabedoria, em estatura e em graça, diante de Deus e diante dos homens" (Lc 2,52); "E o Verbo se fez carne e habitou entre nós" (Jo 1,14). (GILBERT; ALETTI, 1985, p. 65). ${ }^{9}$

Considerando os dados bíblicos e, sobretudo, evidências evangélicas, pode-se concluir que Jesus foi interpretado como a encarnação da Sabedoria divina. Sendo a sabedoria um substantivo feminino, tanto em hebraico (hokmah) quanto em grego (sofia) e tendo ela características femininas, isso favorece uma leitura feminista, para abrandar o paradigma do salvador masculino. Mas passamos para a exposição do Jesus histórico, sábio popular, mestre de sabedoria, que é o objeto mais específico deste artigo.

\section{JESUS É UM SÁBIO POPULAR}

Jesus é, sem dúvida, em muitos textos evangélicos, identificado como um sábio, como mestre de sabedoria, e como quem ensina com autoridade. O seu estilo, usando ditos, provérbios e parábolas (mašal) é o de um sábio; Ele se apresenta como tal; usa a sabedoria popular para transmitir seus ensinamentos de mestre. Os provérbios, em geral, não se referem ao relacionamento com Deus, mas com o próximo; visam a ética (ethos); levam a refletir para mudar a vida e a sociedade (CERESKO, 2004, p. 186-191).

Isso posto, podem-se fazer algumas deduções:

A familiaridade de Jesus com o uso de provérbios, ditos e expressões proverbiais demonstra a sua identificação como um sábio popular. Ele se situa na tradição da sabedoria prática, que orienta sobre questões cotidianas da vida (BEARDSLEE,

${ }^{9}$ As citações bíblicas, normalmente, são feitas a partir da tradução da Bíblia de Jerusalém (2012). 
1970, p. 62-63). ${ }^{10}$ Assim é o seu trato com assuntos como semeadura e colheita, joio e trigo, fermento e moeda, tesouro e pérola ou rede de pesca, conforme ilustrado na composição de parábolas de Mateus (Mt 13). Nesse reconhecimento de Jesus como sábio popular, ele poderia até ser identificado como um filósofo ambulante, a exemplo dos cínicos, trazendo novo ethos, proposta de viver sem bens, sem família, sem pátria, conforme expresso no chamado discurso missionário (Mt 10), e bem desenvolvido em tese (SILVA, 2001).

Vários dados dos Evangelhos corroboram a identificação de Jesus como sábio. Jesus é um mestre de sabedoria, como exemplificado no Sermão da Montanha (Mt 5) e em muitos outros textos; as pessoas se maravilham com sua sabedoria e se perguntam: "De onde vem essa sabedoria?"; "Não é ele o filho do carpinteiro?" (Mt 13,54.55); a sabedoria trazida por Jesus é ocultada aos sábios e revelada aos pequeninos (Mt 11,25); com o provérbio, Jesus chama a atenção para uma situação corrente e sacode quem ouve, para um novo sentido da realidade e para novas decisões de vida.

\subsection{Jesus cita provérbios do Antigo Testamento}

Frequentemente, os Evangelhos colocam na boca de Jesus, citações de provérbios do Antigo Testamento. Essas citações, ora literais, ora de livre tradução, demonstram a liberdade com que os evangelistas, e o próprio Jesus, manejavam os ditos populares. Demonstram também, por outra parte, que os ditados circulavam como unidades independentes, e podiam ser adaptados a lugares e a situações distintas. Para ilustrar essa realidade, basta o exemplo da chamada regra de ouro, aqui sintetizado a partir da explicação de Crossan (1983, p. 50-54):11

"Tudo aquilo, portanto, que quereis que os homens vos façam, fazei-o vós a eles, pois esta é a Lei e os Profetas" (Mt 7,12). A formulação de Mateus é positiva e está

\footnotetext{
${ }^{10}$ Após analisar três obras (de Bultmann; de Küchler e de Beardeslee) sobre provérbios sapienciais como palavras de Jesus, Westermann conclui que: "Jesus não é apresentado como um mestre de sabedoria abstrata, didática (como, por exemplo, em Provérbios 1-9); ao contrário, ele é alguém que recebeu a sabedoria proverbial dos pais" (WESTERMANN, 1995, p. 115).

${ }_{11}$ Crossan (1983) analisa, nessa perspectiva, outros ditos, além deste aqui sintetizado, tais como "os primeiros serão os últimos" (p. 42-47); "quem não está comigo está contra mim" (p. 47-50); "arrependei-vos, o Reino está próximo" (p. 54-56) e "a hora em que vem o ladrão" (p. 57-65).
} 
contextualizada após a recomendação "pedi e vos será dado" e antes da outra recomendação "entrai pela porta estreita". A formulação de Lucas é também positiva, mas está num contexto bem diferente, inserida na recomendação do amor aos inimigos: "Como quereis que os outros vos façam, fazei também a eles" (LC 6,31). O dito se encontra no livro de Tobias, mas com formulação negativa: "Não faças a ninguém o que não queres que te façam" (Tb 4,15). Também é citado de forma negativa no Evangelho de Tomé: "Não faças o que odeias" (Tomé 6b); e na Didaqué: "E aquilo que não farias a ti mesmo; não faças ao outro" (Didaqué $1,2 \mathrm{~b}$ ). $\mathrm{A}$ formulação, como tal, não consta em Marcos, o que confirmaria a sua origem na fonte Q. Poderia refletir, entretanto, o sentido da citação de Marcos, com formulação similar: "Amarás o teu próximo como a ti mesmo" (Mc 12,31), citação literal de LV 19,18, e que, como tal, consta também nos paralelos de Mateus e Lucas, bem como na Didaqué. A variação positiva ou negativa do provérbio não implica juízo de valor, mas demonstra apenas uma diversidade de formulação. A expansão em Mateus "pois esta é a lei e os profetas" (Mt 7,12) se assemelha àquela atribuída a Hillel o Velho (entre 20 a.C. e 20 d.C.): "O que é odioso a ti, não faças a ninguém mais; isso é toda a Lei, tudo o mais é comentário. Vai e aprende".

As referências ao Antigo Testamento, entretanto, ocorrem, de maneira mais intensa, no chamado Sermão da Montanha (Mt 5-7), que possui um fundo sapiencial, sobretudo na sabedoria do livro de Provérbios. Alguns exemplos podem ilustrar a afirmação (HORTON, 1888, p. 109-112).

"Felizes os pobres em espírito" (Mt 5,3); tem um sentido correspondente em: "É melhor ser humilde com os pobres que repartir despojos com os soberbos" ( $\mathrm{Pr}$ 16,19). "Felizes os mansos, porque herdarão a terra" (Mt 5,4); é citação de: "Porque os retos habitarão a terra" ( $\operatorname{Pr} 2,21$; cf. 10,30). "Felizes os que promovem a paz" (Mt 5,9) é citado de: "Aos conselheiros que promovem a paz: a alegria" ( $\operatorname{Pr} 12,20)$. "A lâmpada do corpo é o olho. Portanto, se teu olho estiver são, todo o teu corpo ficará iluminado" (Mt 6,22); reflete o sentido do provérbio: "A lâmpada de Yhwh é o espírito do homem, a qual penetra até o fundo de seu ser" (Pr 20,27). 
Esses exemplos, entre tantos, demonstram a familiaridade de Jesus e das primeiras comunidades cristãs com a sabedoria proverbial. Demonstram, igualmente, a liberdade com que os aplicavam e os novos sentidos que Ihes atribuíam.

\subsection{Jesus usa provérbios da literatura}

O item anterior já tem demonstrado como os provérbios citados no Evangelho ultrapassam os limites da Bíblia Hebraica. Dado o universalismo dos ensinamentos transmitidos pelos vários ditos, eles podem ser comuns a diversas culturas e ambientes. No caso de Jesus, como judeu da Galileia, as metáforas utilizadas provêm mais daquele ambiente agrícola pastoril. Porém como a Galileia é uma província dos confins do Império Romano, seu ambiente não deixa de ser atingido pela cultura greco-romana, ali popularizada. Assim sendo, as citações proverbiais de Jesus possuem paralelos tanto nos rabinos quanto nos literatos da época (CARLSTON, 1980, p. 87-105).

Os ditos de Jesus, apresentados nos Evangelhos Sinóticos, faziam parte da tradição judaica, conservada nos escritos rabínicos, e condensada em coleções como Talmudim, Mishnaiot, Midrashim etc. Dos termos analisados por Araújo (2016, p. 141-156), Reinado (reino) dos céus, Éon, Pai, sintetizamos os dados sobre a expressão "Pai que estais nos Céus". Assim figura no início da oração: "Pai nosso que estás nos céus" (Mt 6,9); e no louvor pela revelação aos pequeninos: "Eu te louvo, ó Pai, Senhor do céu e da terra" (Mt 11,25; Lc 10,21). Marcos não usa a mesma expressão, mas cita da boca de Jesus o termo aramaico 'abba (Mc 14,36), que seria original de Jesus e que não é citado pelos rabinos. Afora a referência a Deus como 'abba, a invocação "Pai que estás nos céus" é comum na tradição rabínica, como nos textos seguintes (citados por ARAÚJO, 2016, p. 148-150):

Exaltado e santificado seja o teu grande nome...

Que ele estabeleça seu Reino em vossa vida...

Que as preces e súplicas de todo Israel sejam

Aceitáveis perante seu Pai que está no céu... (prece do Kadish).

A cada vez que os israelitas dirigiam seus pensamentos aos céus, submetiam seu coração a seu pai que está nos céus, eles saíam vitoriosos... (MRosh hashaná III,8). 
Judá ben Tema disse: Sede fortes como o leopardo e ligeiros como a águia... bravos como o leão para fazer a vontade de vosso pai que está nos céus (MAvot $\mathrm{V}, 20$ ).

Em quem confiaremos? Em nosso Pai que está nos céus (MSotá IX, 15).

O mestre Jesus não se restringe ao seu contexto palestino, mas cita, não raro, provérbios da literatura corrente, do mundo greco-romano de então, conforme alguns exemplos, dentre outros citados por Carlston (1980, p. 99).

Assim: "Nada há de encoberto que não venha a ser descoberto, nem de oculto que não venha a ser revelado" (Mt 10,26); possui semelhança com a citação de Diógenes Laércio: "O tempo traz todas as coisas à luz"; ou com a de Publílio: "O tempo esconde o réprobo e o tempo o revela".

O famoso: "Médico, cura-te a ti mesmo" (Lc 4,23), tem ecos da citação de Diógenes: "Bem, os médicos ... estão atendendo os doentes sem cuidar da própria febre". O tema da medicina serviu a diversos ditos das culturas antigas. Assim: "Não são os que têm saúde que precisam de médico, mas os doentes" (Mc 2,17); tem correspondência em Menandro: "Aquele cujo corpo está doente, precisa de um médico..."; ou em outra de Diógenes: "Torna-se doente quem faz de seu médico seu herdeiro".

"Com a medida com que medis sereis medidos" (Mt 7,2); pode ser comparado com a exortação de Hesíodo: "Tome uma medida justa com seu vizinho e retribua-o com a mesma medida ou melhor, se puder".

Isso demonstra o universalismo da mensagem de Jesus, como o universalismo dos ditados, presente nos principais conceitos sapienciais, que envolvem os diversos aspectos da realidade. Provérbios abrangem, efetivamente, todas as ambiguidades e paradoxos da vida, tais como tradicional e novo, erudito e popular, nacional e estrangeiro, pobre e rico, homem e mulher, criança e pessoa idosa... (SILVA, 2018, p. 17-42).

\subsection{Jesus parte de provérbios para compor parábolas}


Provérbio e parábola, como já explicado, constituem um conceito único em hebraico, aramaico e grego. Na brevidade do dito sapiencial, pela metáfora utilizada, pode se desenrolar uma longa história. Conforme Cervantes (citado na abertura do livro de PESTANA, 2002, p. 15): "Um provérbio é uma frase curta baseada numa experiência longa". Para além dessa realidade constatada nos vários ditos de Jesus, a relação entre provérbio e narrativa é mais ampla. Isso envolve, uma vez mais, o fato que as expressões proverbiais possuem caráter universal, mas se aplicam a situações particulares. Jesus amplia o sentido de aforismos para compor parábolas (BEARDSLEE, 1970, p. 65).

Do provérbio: "Quando vem a tormenta, desaparece o ímpio" ( $\operatorname{Pr} 10,25$; cf. 12,7) compõe-se a parábola da casa construída sobre a rocha (Mt 7,24-27). Do provérbio: "Com paciência dobra-se um magistrado, e a língua macia pode quebrar ossos" ( $\mathrm{Pr}$ 25,15; cf. 15,1), provém o motivo da parábola do juiz e da viúva (Lc 18,1-8). Do provérbio: "Quem esconde suas faltas jamais tem sucesso, mas quem as confessa e abandona obtém compaixão" ( $\operatorname{Pr} 28,13$; cf. 28,9), faz-se a parábola do fariseu e do publicano (LC 18,9-14).

Observa-se, a partir dessa constatação, que poderia ser estendida a muitos outros exemplos, a capacidade de Jesus em adaptar um dito sapiencial e aplicá-lo a determinada situação específica, demonstrando assim, que a verdade universal de um dito pode se adequar a uma determinada situação da história de vida real.

\subsection{Jesus apela para o paradoxo}

O sentido dos provérbios é intensificado através do paradoxo, que consiste no jogo de antíteses entre tipos humanos ou formas de existência, como em ser o primeiro ou ser o último, perder a vida ou ganhar a vida, ser exaltado ou ser humilhado. $O$ paradoxo é das fórmulas mais comuns utilizadas nos provérbios e, possivelmente, das mais antigas, como ilustra a citação: "O filho sábio alegra o pai, o filho insensato entristece a mãe" ( $\operatorname{Pr} 10,1)$. A antiga fórmula paradoxal se baseia na inversão da existência ou "inversão de status". Os Evangelhos apelam frequentemente para essa proposição, como em: "Quem se exalta será humilhado e quem se humilha será exaltado" (Lc 14,11; cf. 18,14; Mt 23,12). A antiguidade da fórmula se confirma em antiga fonte babilônica, cerca de 1440 a.C. "Se (alguém pensa) 'eu sou herói', ele 
será envergonhado; se (alguém pensa) 'eu sou fraco', ele será poderoso" (BEARDSLEE, 1970, p. 66).

Outros exemplos podem ser citados, a partir de Beardslee (1970, p. 67): "Muitos dos primeiros serão últimos" (Mc 10,31; cf. Mt 20,16; Lc 13,30); "Que aproveita ao homem ganhar o mundo inteiro e arruinar sua própria vida?" (Mc 8,36 par); "Aquele que dentre vós quiser ser grande, seja o vosso servidor, e aquele que quiser ser o primeiro dentre vós seja o servo de todos" (Mc 10,43-44 par); "Quem procurar ganhar sua vida, vai perdê-la, e quem a perder vai conservá-la" (Lc 17,33; cf. Mc 8,35 par; Jo 12,25).

O paradoxo, ao jogar com o contraste extremo, quer chocar a atenção das pessoas que ouvem, a fim de provocar uma mudança de atitude, ou mesmo despertar para uma tomada de posição arrojada. ${ }^{12}$

\subsection{Jesus apela para a hipérbole}

Ampliando a compreensão de paradoxo, pode-se caracterizar a hipérbole, como a linguagem intensificada pelo exagero. Trata-se de um recurso comum nos provérbios, em vista do impacto que eles pretendem criar. Seguem-se alguns exemplos citados por Beardslee (1970, p. 68).

"Se tiveres fé como um grão de mostarda, direis a esta montanha: transporta-te daqui para lá, e ela se transportará" (Mt 17,20; cf. Lc 17,6; Mc 11,23; Mt 21,21). "É mais fácil um camelo passar pelo fundo da agulha do que um rico entrar no Reino de Deus" (Mc 10,25 par). As hipérboles têm sua expressão mais intensa nas Bemaventuranças, com um entre vários exemplos: "Amai vossos inimigos, fazei o bem aos que vos odeiam" (Lc 6,27).

A diferença entre o paradoxo e a hipérbole, de fato, é relativa, visto que fazem parte do mesmo recurso, que é criar impacto na audiência. Tal extremismo pode comprovar, também o caráter original da aplicação do provérbio por parte de Jesus, como no contexto do seguimento, com a série: "As raposas têm tocas e as aves do

\footnotetext{
12 Segundo Carlston (1980, p. 103), esses paradoxos entre morte e vida ou entre humilhação e exaltação adquiriram, no cristianismo primitivo, caráter kerigmático e escatológico, à luz da morte e ressurreição de Jesus.
} 
céu, ninhos; mas o Filho do Homem não tem onde reclinar a cabeça" (Lc 9,58; cf. Mt 8,20). "Deixa que os mortos enterrem seus mortos" (Lc 9,60; cf. Mt 8,22). "Quem põe a mão no arado e olha para trás não é apto para o Reino de Deus" (Lc 9,62). (CARLSTON, 1980, p. 103).

\subsection{Jesus apela para o humor e o sarcasmo}

Assim como o paradoxo e a hipérbole expressam a força da linguagem proverbial, assim também o humor é frequente nos ditos de Jesus, como na linguagem proverbial em geral. Há nos ditos de Jesus uma espécie de humor sarcástico, a fim de provocar a audiência, como anota Beardslee (1970, 68): "Condutores cegos, que coais o mosquito e engolis o camelo" (Mt 23,24); ou: "Hipócrita, tira a trave do teu olho, e então verás bem para tirar o cisco do olho do teu irmão" (Mt 7,5).

Ao constatar a falta de humor, frequente na teologia, liturgia e estudos bíblicos, Hand (2013, p. 119) argumenta: "Jesus sabia como pensar duramente, como fazer o tipo de piada que os camponeses fazem, e como usar essas piadas subversivamente para aumentar a consciência social". Dentre outros exemplos, o autor apresenta a parábola do banquete (Lc 14,15-24), com a rejeição, pelos convidados, com as desculpas da compra de um terreno, ou de uma junta de bois ou por ter-se casado, em favor do convite a pobres, estropiados, cegos e coxos (v. 21).

O humor sarcástico de Jesus é mais refinado com relação às autoridades de sua época. Com relação ao tributo cobrado pelos "reis da terra", Jesus, ironicamente, se dirige a Pedro: "Para que não os escandalizemos, vai ao mar e joga o anzol. $O$ primeiro peixe que subir, segura-o e abre-lhe a boca. Acharás aí um estáter. Pega-o e entrega-o a eles por mim e por ti” (Mt 17,27). Em resposta aos fariseus e herodianos, sobre o pagamento da moeda ao imperador romano, autoridade máxima, ele ordena: "O que é de César, devolvei a César; o que é de Deus, a Deus" (Mc 12,17). Ao rei Herodes, que ameaçava matá-lo, ele manda um recado sarcástico: "Ide dizer a essa raposa..." e conclui com o dito: "Não convém que um profeta morra fora de Jerusalém" (Lc 13,32.33). 


\section{CONSIDERAÇÕES FINAIS}

A familiaridade de Jesus com o uso de ditos, provérbios e parábolas, conforme atestado nos Evangelhos, o identifica como um sábio popular, na esteira da tradição sapiencial de Israel. A identificação de Jesus como sábio, tem levado a identificá-lo como a própria sabedoria divina personificada ou como um mestre de sabedoria popular, contador de causos junto à população do seu ambiente de convivência. Os dois aspectos, embora não configurem um dualismo, segundo a abordagem dos próprios Evangelhos, podem ser abordados separadamente, de maneira didática e organizada. Foi o que pretendemos fazer, no desenvolvimento deste estudo.

Destacamos o aspecto histórico de Jesus, reconhecido como profeta sábio popular, perambulando por aldeias e povoados, conversando sobre os problemas de seu ambiente, provocando as pessoas com ditos ardilosos, com finalidade didática, para despertar a consciência crítica, a fim de provocar tomadas de posição pessoais, em vista de mudanças sociais maiores. Tal aspecto histórico de Jesus se manifesta igualmente nas parábolas, já estudadas com maior frequência do que os provérbios. Daí a importância de retornar com mais intensidade a esse aspecto, para abrir novos horizontes na compreensão da Boa Nova.

O assunto tem despertado maior interesse, nos tempos recentes, mas permite novos avanços. No continente latino-americano e, mais especificamente, no Brasil, essa caminhada avança. Que ela se acelere sempre mais!

\section{REFERÊNCIAS}

ARAÚJO, Reginaldo Gomes de. Os ditos de Jesus e os escritos rabínicos. Cadernos de Língua e Literatura Hebraica, n. 14, p. 141-156, 2016. Disponível em: https://www.revistas.usp.br/cllh/article/view/125037 Acesso em 10 jun. 2021.

BEARDSLEE, William A. Uses of the Proverb in the Synoptic Gospels. Interpretation, v. 24, n. 1, p. 61-73, Jan 1970.

Bíblia de Jerusalém. GORGULHO, Gilberto da Silva; STORNIOLO, Ivo; ANDERSON, Ana Flora Anderson (Coords.). São Paulo: Paulus, 2012. 
CARLSTON, Charles E. Proverbs, Maxims, and the Historical Jesus. Journal of Biblical Literature, v. 99, n. 1, p. 87-105, 1980.

CERESKO, Anthony R. A Sabedoria no Antigo Testamento: espiritualidade libertadora. São Paulo: Paulus, 2004.

CHEVITARESE, André Leonardo; FUNARI, Pedro Paulo A. Jesus histórico: uma brevíssima introdução. Rio de Janeiro: Kline, 2012.

CROSSAN, John Dominic. In Fragments: The Aphorisms of Jesus. San Francisco: Harper \& Row, 1983.

DIAS DA SILVA, Cássio Murilo. Mas... o que é mesmo uma parábola? In: ROSSI, Luiz Alexandre Solano; SILVA, Valmor da (Orgs.). Parábolas na Bíblia. São Paulo: Paulus, 2019. p. 11-32).

FERREIRA, Valdivino José. A pedagogia de Jesus através do uso de provérbios segundo o Evangelho de Lucas. Tese de Doutorado. Goiânia: PUC Goiás, 2020. http://tede2.pucgoias.edu.br:8080/handle/tede/4546

FUNK, Gabriela. A Bíblia como indicador da importância do provérbio no âmbito de culturas diferentes. Paremia, Madrid, n. 7, p. 97-106, 1998.

https://cvc.cervantes.es/Lengua/paremia/pdf/007/012 funk.pdf

GILBERT, Maurice e ALETTI, Jean-Noël. A Sabedoria e Jesus Cristo. São Paulo: Paulinas, 1985. (Cadernos Bíblicos, 32).

GUIJARRO OPORTO, Santiago. Ditos primitivos de Jesus: uma introdução ao "Proto-evangelho de ditos Q". São Paulo: Loyola, 2006.

HAMILTON, Victor P. Mashal. In: COENEN, Lothar; BROWN, Colin. (Orgs). Dicionário Internacional de Teologia do Novo Testamento. São Paulo: Vida Nova, 2000. p. 889-890.

HAND, Karl. A Wicked Sense of Humor. Theology Today, v. 70, n. 1, p. 119-127, 2013.

HEDRICK, Charles W. The Wisdom of Jesus: Between the Sages of Israel and the Apostles of the Church. Eugene: Cascade, 2014.

HORTON, R. F. Christ's Use of the Book of Proverbs. The Expositor, v. 7, series 3, p. 105-123, 1888.

HUMPHREY, Hugh M. Jesus as Wisdom in Mark. Biblical Theology Bulletin, v. 19, n. 2, p. 48-53, Apr 1989.

NGUYEN, Dinh Anh Nhue. Gesù il saggio di Dio e la Sapienza divina: Indagine biblico-teologica introdutiva per ripensare la cristologia sapienziale nei vangeli sinottici. Roma: Miscellanea Francescana, 2017.

$\mathrm{NICCACCl}$, Alviero. A casa da sabedoria: vozes e rostos da sabedoria bíblica. São Paulo: Paulinas, 1997.

PATTERSON, Stephen J. Wisdom in Q and Thomas. In: PERDUE, Leo G.; SCOTT, Bernard Brandon; WISEMAN, William Johnston (Editors). In Search of Wisdom: 
Essays in Memory of John G. Gammie. Louisville: Westminster/John Knox Press, 1993, p. 187-221.

PESTANA, Álvaro César. Provérbios do homem-Deus: frases poderosas de Jesus de Nazaré. São Paulo: Vida Cristã, 2002.

PIPER, Ronald A. Wisdom in the Q-Tradition: The aphoristic teaching of Jesus. Cambridge: Cambridge University Press, 1989.

RODRIGUES, Elisa. Jesus e as tradições sapienciais no "Evangelho radical Q". Estudos Bíblicos. Petrópolis, n. 99, p. p. 51-64, 2008.

SCHIAVO, Luís; SILVA, Valmor da. Jesus, milagreiro e exorcista. São Paulo: Paulinas, 2002.

SILVA, Clemildo Anacleto da. Jesus: sábio, profeta ou filósofo? Análise comparativa da crítica social e de valores na fonte dos ditos de Jesus, nos filósofos cínicos e nos testamentos dos doze patriarcas. Tese de Doutorado. São Bernardo do Campo: UMESP, 2001.

SILVA, Valmor da. O caminho da justiça na sabedoria dos provérbios. São Paulo: Paulus, 2018.

VAAGE, Leif E. O cristianismo galileu e o evangelho radical de Q. Revista de Interpretação Bíblica Latino-Americana, RIBLA, Petrópolis, n. 22, p. 84-108, 1995.

VÍLCHEZ LíNDEZ, José. Sabedoria e sábios em Israel. São Paulo: Loyola, 1999. (Bíblica Loyola, 25).

WESTERMANN, Claus. Roots of Wisdom: The Oldest Proverbs of Israel and Other Peoples. Louisville: Westminster John Knox Press, 1995. 